\title{
Turbulent heat fluxes during an intense cold-air outbreak over the Kuroshio Extension Region: results from a high-resolution coupled atmosphere-ocean model
}

\author{
Tommy G. Jensen • Timothy J. Campbell • \\ Richard A. Allard • Richard Justin Small • \\ Travis A. Smith
}

Received: 29 September 2010 / Accepted: 12 January 2011 /Published online: 12 February 2011

(C) Springer-Verlag (outside the USA) 2011

\begin{abstract}
The coupled ocean atmosphere mesoscale prediction system that includes the Navy Coastal Ocean Model has been configured for the Kuroshio Extension region using multiple one-way nested high-resolution grids. The coupled model system was used to simulate a strong cold-air outbreak event from 31 Jan to 7 Feb 2005 in good agreement with meteorological data from a surface buoy data and QuikSCAT scatterometer winds. Latent heat fluxes and sensible heat fluxes were computed during the event with daily averages in excess of $1,500 \mathrm{~W} / \mathrm{m}^{2}$ and $500 \mathrm{~W} / \mathrm{m}^{2}$, respectively, and combined instantaneous turbulent heat fluxes up to $2,300 \mathrm{~W} /$ $\mathrm{m}^{2}$. The largest heat fluxes were found in two large meanders of the Kuroshio and along its southern flank. Strong gradients in turbulent heat fluxes coincided with strong sea surface temperature gradients and were maintained during the cold-air outbreak simulation. The large turbulent heat fluxes lead to significant subtropical mode water formation during the event at a rate about $10 \mathrm{~Sv}$ in the
\end{abstract}

Responsible Editor: Tal Ezer

This article is part of the Topical Collection on 2nd International Workshop on Modelling the Ocean 2010

T. G. Jensen $(\bowtie) \cdot$ T. J. Campbell • R. A. Allard · T. A. Smith Oceanography Division, Naval Research Laboratory,

Code 7322,

Stennis Space Center, MS 39529-5004, USA

e-mail: Tommy.Jensen@nrlssc.navy.mil

R. J. Small

Climate and Global Dynamics Division,

National Center for Atmospheric Research,

1850 Table Mesa Drive,

Boulder, CO 80305-5602, USA cyclonic recirculation region south of the Kuroshio. This increased the volume of core layer mode water within the temperature range $16^{\circ} \mathrm{C}$ to $18^{\circ} \mathrm{C}$ by $10 \%$ and increased the surface area of that layer directly exposed to the atmosphere by a factor close to 5 in the model domain.

Keywords Air-sea interaction · Heat flux · Winter storm . Warm pool $\cdot$ Kuroshio $\cdot$ Coupled model

\section{Introduction}

The western boundary current regions are areas with large heat losses from the ocean to the atmosphere. Based on the 40-year re-analysis from the European Centre for Medium-Range Weather Forecasts, the annual mean latent heat flux to the atmosphere in the Kuroshio and Gulf Stream is about 200 W/ $\mathrm{m}^{2}$ (e.g., Kallberg et al. 2005). The largest latent heat loss occurs during the winter season with a cooling rate of about $340 \mathrm{~W} / \mathrm{m}^{2}$ during December and January, a calculation based on monthly data from 1981 to 2000 from the synthesis by $\mathrm{Yu}$ and Weller (2007). However, the heat fluxes are highly variable due to weather events. During winter, when cold continental air masses flow over the subtropical waters, which are located equatorward of the western boundary currents (e.g., the Gulf Stream or the Kuroshio), the daily averaged latent and sensible heat fluxes computed from bulk formulations can be more than twice the monthly averages (Qiu et al. 2004; Bond and Cronin 2008) . For instance, during an event in the Gulf Stream region, Grossman and Betts (1990) found that turbulent heat fluxes were in excess of $1,000 \mathrm{~W} / \mathrm{m}^{2}$ based on detailed measurements from aircrafts. 
The motivation for this study is to examine how much impact a single intense cold-air outbreak event can have on the upper ocean and how large values of the surface heat fluxes may be in such events. During a typical year, there are 13 relatively strong cold-air events of very cold Siberian air being advected over the Sea of Japan towards the Kuroshio Extension Region (Dorman et al. 2004). The event presented in this paper is among the most intense and long-lasting based on turbulent heat flux calculations from observations at the Kuroshio Extension Observatory (e.g., Kubota et al. 2008; Bond and Cronin 2008; Konda et al. 2010).

\subsection{Cold-air outbreaks}

The advection of cold, polar air masses are synoptic events that typically last 2-3 days, often resulting in rapid cyclogenesis and are associated with high wind speeds. This important weather phenomenon has been investigated in several observational experiments. A major undertaking was done under the Genesis of Atlantic Lows Experiment that aimed to investigate rapidly developing storms off the East Coast of North America (Dirks et al. 1988). The Air Mass Transformation Experiment (AMTEX), which took place during winters in 1974 and 1975, was launched to study cold-air outbreaks from the Asian continent over subtropical waters in the East China Sea (e.g., Lenschow and Agee 1976).

Several numerical modeling studies have been done for cold-air flows. Sun and Hsu (1988), using a twodimensional planetary boundary layer model for the East China Sea, found good agreement with AMTEX observations and sensible and latent heat fluxes of 300 and $700 \mathrm{Wm}^{-2}$, respectively, which are close to the observed values. Xue et al. $(1995,2000)$ used a two-dimensional numerical coupled atmosphere-ocean model for cold-air outbreaks and found maximum heat fluxes of 1,500 and $1,300 \mathrm{Wm}^{-2}$, respectively. Modeling of cold-air outbreaks using a full three-dimensional coupled atmosphere-ocean model was done for the Gulf Stream for a 48-h cold-air outbreak in January 1998 over the Gulf Stream (Li et al. 2002). They found a maximum sensible heat flux of $273 \mathrm{~W}$ $\mathrm{m}^{-2}$ and a maximum latent heat flux of $575 \mathrm{Wm}^{-2}$.

In this study, we present a case from 30 January through 6 February 2005 where the formation of cyclones followed the initial cold-air outbreak. Development was fairly rapid, with the atmospheric low pressure falling nearly $1 \mathrm{hPa}$ per hour during $24 \mathrm{~h}$ and thus, just short of the definition of atmospheric bombs (Sanders and Gyakum 1980). The event was captured by the National Oceanographic and Atmospheric Administration (NOAA) Kuroshio Extension Observatory (KEO) buoy and by satellite observations.
1.2 The Kuroshio Extension system region and North Pacific subtropical mode water

The Kuroshio Extension region is the source region for North Pacific Subtropical Mode Water (NPSTMW) which forms between the coast of Japan and about $175^{\circ} \mathrm{E}$ in the latitude band $30^{\circ} \mathrm{N}$ to $35^{\circ} \mathrm{N}$. It is often defined as a homogeneous water mass between the seasonal thermocline and the main thermocline, with a vertical minimum in potential vorticity and is identified as a thermostat with a temperature range of $16^{\circ} \mathrm{C}-19^{\circ} \mathrm{C}$ (e.g., Masuzawa (1969); Hanawa and Suga 1995). Different authors give different temperature and salinity ranges for NPSTMW and note that the temperatures of NPSTMW vary with time and space. For instance, Oka and Suga (2003) characterize the formation region during the winter to have a narrower temperature range of $16.5^{\circ} \mathrm{C}$ to $18.2^{\circ} \mathrm{C}$.

During the northern winter, when cold outbreaks of continental air masses spread eastward over the warm water south of the Kuroshio, large heat losses to the atmosphere result in episodes of oceanic convection, forming NPSTMW (Masuzawa 1969; Suga et al. 1989; Bingham 1992; Suga and Hanawa 1995; Hanawa and Suga 1995; Oka and Suga 2003). According to these studies, the water mass forms in a mixed layer deeper than $200 \mathrm{~m}$, and its core layer temperature and salinity range is $16^{\circ} \mathrm{C}$ to $18.2^{\circ} \mathrm{C}$ and 34.75 to 34.85 psu, respectively. Particularly favorable conditions for NPSTMW formation exist when the Kuroshio Extension is in a stable mode and the stratification is not subject to mixing associated with intense eddies as found during times when the Kuroshio has large meanders (Qiu and Chen 2006).

The impact of the cold/warm water front on the atmosphere over the Kuroshio and Gulf Stream regions has been well-documented to include low-level moisture convergence, deepening of the planetary boundary layer, and generation of storms (e.g., Sun and Hsu 1988; Xue et al. 1995, 2000). Recent discussions are given by Minobe et al. (2008), Small et al. (2008), Taguchi et al. (2009), and Tokinaga et al. (2009).

\section{Data and model}

\subsection{The Kuroshio Extension Observatory}

The KEO surface buoy deployed by NOAA began its measurements in June 2004 and is still in operation as of December 2010. It is located in the subtropical warm pool region at $144.6^{\circ} \mathrm{E}, 32.4^{\circ} \mathrm{N}$ and has measured surface meteorology and upper ocean quantities. During the time that covers the event of interest, the buoy measured wind speed and direction, air temperature, relative humidity, precipitation, 
short-wave and long-wave radiation, and $\mathrm{CO}_{2}$ flux with 10 min interval. In the ocean, temperature and salinity was measured to a depth of $500 \mathrm{~m}$ during this event.

2.2 Woods Hole Oceanographic Institution objectively analyzed air-sea fluxes

The OAFlux_V3 gridded fluxes combines satellite and in situ data with atmospheric re-analysis products and provides a $1^{\circ}$ by $1^{\circ}$ global data set of daily latent and sensible heat flux as well as radiative fluxes from January 1985 through December 2006 (Yu and Weller 2007). For a 49year time span covering the years 1958 through 2006, monthly data is available.

\subsection{COAMPS atmospheric model}

The Coupled Ocean-Atmospheric Mesoscale Prediction System (COAMPS) developed by the Naval Research Laboratory (NRL; Hodur 1997; Chen et al. 2003) is a limited area atmospheric model used for research and operational forecasts by the US Navy. The system includes a comprehensive atmospheric analysis system (Goerss and Phoebus 1992) that employs a three-dimensional multivariate optimum interpolation method (MVOI; Barker 1992) to assimilate a wide range of surface, radiosonde, and satellite meteorological observations. MVOI is used in this study, but recently, a new three-dimensional variational data assimilation system, the NRL Atmospheric Variational Data Assimilation System has been made available for COAMPS (Langland and Baker 2004). The analysis uses a $1^{\circ}$ by $1^{\circ}$ grid and 16 vertical levels. COAMPS was set up over the northwestern Pacific Ocean as described below.

The atmospheric model covers the Kuroshio Extension System Study (KESS) region over an area of about 5,400 by $2,700 \mathrm{~km}$ using a Lambert conformal projection centered on $142^{\circ} \mathrm{E}, 35^{\circ} \mathrm{N}$, extending from the Asian continent to the date line and from about $25^{\circ} \mathrm{N}$ to $45^{\circ} \mathrm{N}$. The model uses three one-way nested grids. The resolution is $27 \mathrm{~km}$ on the coarse grid $(199 \times 100$ grid points). The second grid covers an area from about $140^{\circ}$ E to $155^{\circ} \mathrm{E}$ and $30^{\circ} \mathrm{N}$ to $42^{\circ} \mathrm{N}$ with a resolution of $9 \mathrm{~km}$. This grid covers the active ocean model using a $199 \times$ 169 grid. The finest atmospheric grid, with a $3 \mathrm{~km}$ resolution, extends from about $142 \mathrm{E}$ to $151 \mathrm{E}$ and $32 \mathrm{~N}$ to $38.5 \mathrm{~N}$ and covers the high-resolution inner ocean model grid. This model has a horizontal grid of $283 \times 277$. The areas covered by the atmospheric model grids are shown in Fig. 1 bordered by black solid lines. Since the atmospheric models use a uniform grid Lambert conformal projection, the grid boundaries vary in both longitude and latitude. Figure 1 uses a regular grid in spherical

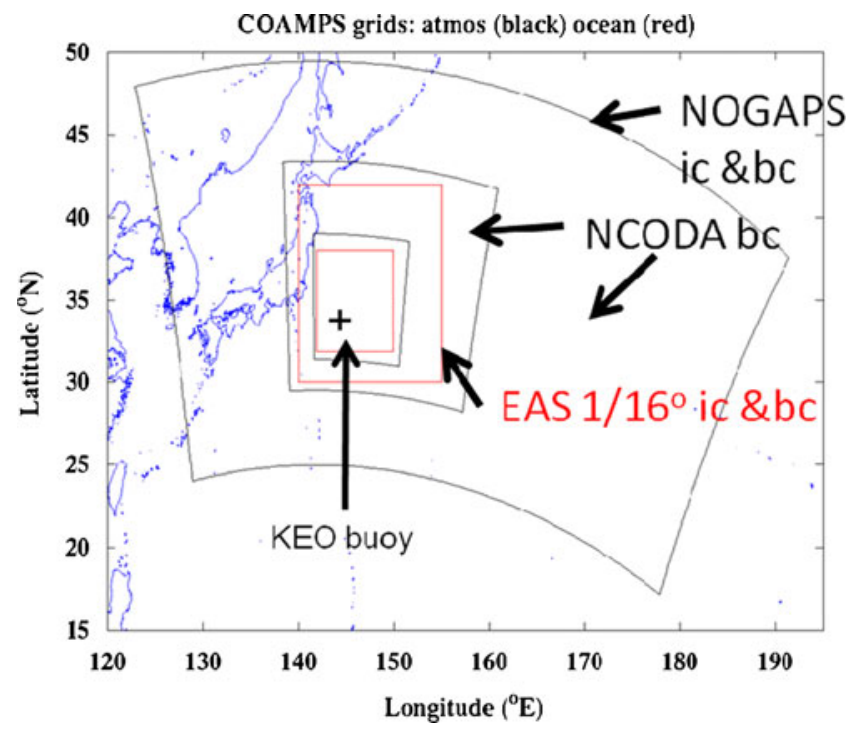

Fig. 1 Model areas and the sources of initial conditions and boundary forcing for the atmospheric model (black lines) and the ocean models (red lines). The location of the Kuroshio Extension Observatory (KEO) buoy is also shown

coordinates, so distances appear distorted, e.g., the southern and northern boundaries on the atmospheric grids have the same length. The atmospheric models use 40 levels in the vertical. The time step is $80 \mathrm{~s}$ in the coarse grid model. Details about the COAMPS atmospheric model can be found in Hodur (1997) and Chen et al. (2003).

\subsection{The Navy Coastal Ocean Model}

The ocean model used is the Navy Coastal Ocean Model (NCOM) developed at the Naval Research Laboratory (Martin 2000). The model has a hybrid sigma-z vertical coordinate and a free surface. It was originally based on the Princeton Ocean Model (POM) by Blumberg and Mellor (1987) and has many aspects common with POM. For instance, it is using the same C-grid layout, the same equation of state (Mellor 1991), the same 2.5-level turbulent closure scheme for vertical mixing (Mellor and Yamada 1982), and the same parameterization for sub-grid scale horizontal mixing (Smagorinsky 1963). A notable difference is the treatment of the barotropic mode. NCOM employs a semi-implicit scheme that uses a pre-conditioned conjugate gradient solver for the resulting elliptic equation whereas POM uses an explicit scheme with time-splitting. NCOM includes river runoff and the eight major diurnal and semi-diurnal tidal constituents (K1, O1, P1, Q1, K2, M2, N2, and S2).

We use a one-way nested model with two grids. The coarser model covers the area from $140^{\circ} \mathrm{E}$ to $155^{\circ} \mathrm{E}$ and $30^{\circ} \mathrm{N}$ to $42^{\circ} \mathrm{N}$ with a horizontal resolution of $1 / 16^{\circ}$ on a 241 
by 193 grid. There are 50 vertical levels: 35 sigma levels with $15 \mathrm{z}$-levels below depths of $550 \mathrm{~m}$. A finer second grid with the same vertical levels and a horizontal resolution of $1 / 48^{\circ}$ covers a region from $142^{\circ} \mathrm{E}$ to $150^{\circ} \mathrm{E}$ and $32^{\circ} \mathrm{N}$ to $38^{\circ} \mathrm{N}$ on a 389 by 293 grid. The ocean model areas are shown in Fig. 1 bordered by full red lines. The grids are uniform in spherical coordinates.

\subsection{Initial conditions and boundary conditions}

Initial and boundary conditions to the atmospheric model come from the Navy Operational Global Atmospheric Prediction System (NOGAPS) and observations. For 30 Jan 20050000 UTC, the atmospheric model is initialized using quality-controlled observations from surface stations, ships, radiosondes, aircraft, and satellites and from a 12$h$ NOGAPS forecast with a spatial resolution of $1^{\circ} \times 1^{\circ}$. The observations and the NOGAPS forecast are analyzed using MVOI and projected onto the atmospheric forecast model grids. The boundary conditions provided by NOGAPS are updated every $6 \mathrm{~h}$.

The ocean model is initialized and its boundaries forced every $6 \mathrm{~h}$ by output from the East Asian Seas NCOM Nowcast/Forecast System (Riedlinger et al. 2006), referred to as EAS16. The EAS16 has the same vertical grid and the same horizontal resolution of $1 / 16^{\circ}$ as the coarse ocean grid, but covering the Western Pacific from $17^{\circ} \mathrm{S}$ to $52^{\circ} \mathrm{N}$ from the Asian continent to $158^{\circ} \mathrm{E}$. The boundary conditions for the EAS16 come from the $1 / 8^{\circ}$ Global NCOM with 40 vertical levels (Barron et al. 2006), and the surface forcing is provided by NOGAPS. Both surface forcing and boundary conditions to EAS16 are provided every $3 \mathrm{~h}$.

Outside the active ocean model area, e.g., the larger box outlined in red in Fig. 1, the SST used to compute fluxes to the atmosphere model is from the Navy Coupled Ocean Data Assimilation (NCODA) analysis (Cummings 2005). This is standard setup for COAMPS when run without an active ocean.

\subsection{Coupling between atmosphere and ocean in COAMPS5}

Surface fluxes are computed in the atmospheric model and the two model components exchange flux information using the Earth System Modeling Framework (www.earth systemmodeling.org) software infrastructure developed by the National Center for Atmospheric Research. We are using version 5 of COAMPS, so, in the reminder of this document, we will refer to the coupled system as COAMPS5. Sea surface temperature is passed from the ocean model to the atmosphere model, and forcing to the ocean model are wind stress components, net surface heat flux, and short-wave radiation. The latter is provided independently to compute penetrative radiation into the ocean. The ocean model SST is used by the atmospheric model to calculate upward long-wave radiation, sensible heat flux, and latent heat flux. A bulk parameterization using the boundary layer formulation by Louis (1979) is used. A coupling interval of $12 \mathrm{~min}$ was used for the coupled model runs presented here. The atmosphere forecast model and ocean model codes used domain decomposition and run in parallel using the Message Passing Interface, which makes the coupled model system run fast and efficient on distributed memory computer architectures.

The coupled model is run with a 12-h update cycle. The diagram in Fig. 2 shows the sequence involved: At the start of a forecast cycle, boundary conditions are provided to the ocean model from EAS16 and from NOGAPS to the atmospheric model. An analysis is done for the atmosphere and for the ocean outside the coupled region. The result of the atmospheric and ocean analysis is used as initial condition for a 12-h forecast. For subsequent forecasts, the analysis uses the previous forecast as a first guess for the analysis, i.e., the atmospheric state will assimilate new observations into a model/data synthesis before the next 12-h forecast. The ocean model is not using any data assimilation in the interior, but along the
Fig. 2 Coupled data assimilation system, where $I C$ denotes initial conditions, $B C$ represents boundary condition and BKG denotes background fields (from Allard et al. 2010a)

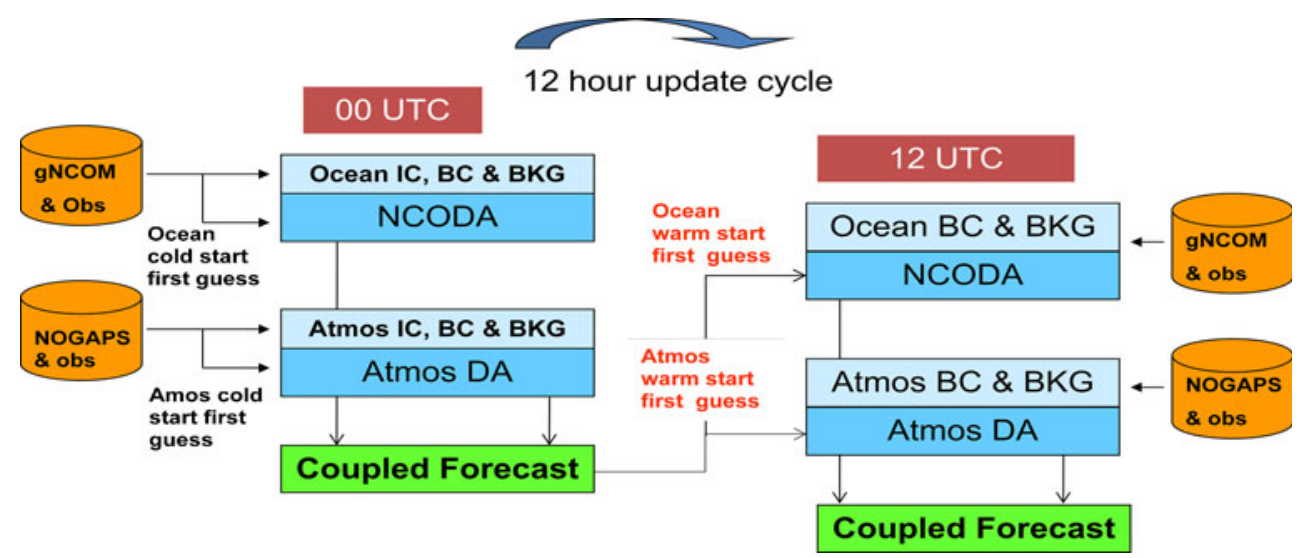


boundaries through the data assimilation employed by EAS16

We also run COAMPS5 where SST is provided by NCODA throughout the entire ocean. We will refer to this as the uncoupled run. These solutions do not include a direct coupling to the model atmosphere and lack feedback to the ocean but serves as a reference solution for comparison. The atmospheric conditions for the coupled and uncoupled runs do not differ significantly, in part, due to data assimilation, but in some cases, there are noticeable differences in surface fluxes. This is due to an absence of small spatial SST scales. During winter, cloud cover limits the available satellite SST observations, so the SST used in NCODA is close to climatology, i.e., much smoother than SST in the ocean model.

\section{Modeled event and comparison with observations}

\subsection{Comparison of COAMPS5 simulation}

with observations

The simulation by the coupled COAMPS5 was started on 30 January 0000 UTC, which is at 9:00 local time in Japan or 10:00 over most of the KESS region. At this initial time, the cold-air outbreak has reached Japan but not the KESS region. In the following, it is shown how the event is found in surface meteorology observations at the KEO site and by QuikSCAT satellite observations and how they compare with our simulation.

\subsection{Observations at the KEO}

At the KEO site, a maximum hourly average wind speed of $19.4 \mathrm{~m} / \mathrm{s}$ was reached at 1 February 1500 UTC or midnight February local time. The maximum wind speed was $21.1 \mathrm{~m} / \mathrm{s} 40 \mathrm{~min}$ later, based on 2-min averaged data with a sampling interval of $10 \mathrm{~min}$. This is well above the average wind speed of $11.9 \mathrm{~m} / \mathrm{s}$ from 30 January to 7 February at the buoy. The wind direction is from the west and west-north-west during this time. Before the onset of the cold-air outbreak, the air and ocean were close to thermal equilibrium with the ocean being only $0.1^{\circ} \mathrm{C}$ warmer than the air which measured $18.5^{\circ} \mathrm{C}$ (Fig. 3). The air temperature reached a minimum of $7.1^{\circ} \mathrm{C}$ on 1 February at 9:10 am local time, which made the air $11.3^{\circ} \mathrm{C}$ colder than the SST. However, the hourly averaged minimum was $8.3^{\circ} \mathrm{C}$ or $10.1^{\circ} \mathrm{C}$ below the hourly mean SST. The average relative humidity was $72 \%$ but was on average $75 \%$ during intense phase the cold-air outbreak, i.e., from 1 February 0000 UTC to 4 February 0000 UTC, with a maximum of $80 \%$.

Observations at KEO were used in the MVOI data assimilation for the atmosphere and do not provide an
Fig. 3 Hourly averages of meteorological observations at the KEO buoy (adapted from Jensen et al. 2009)

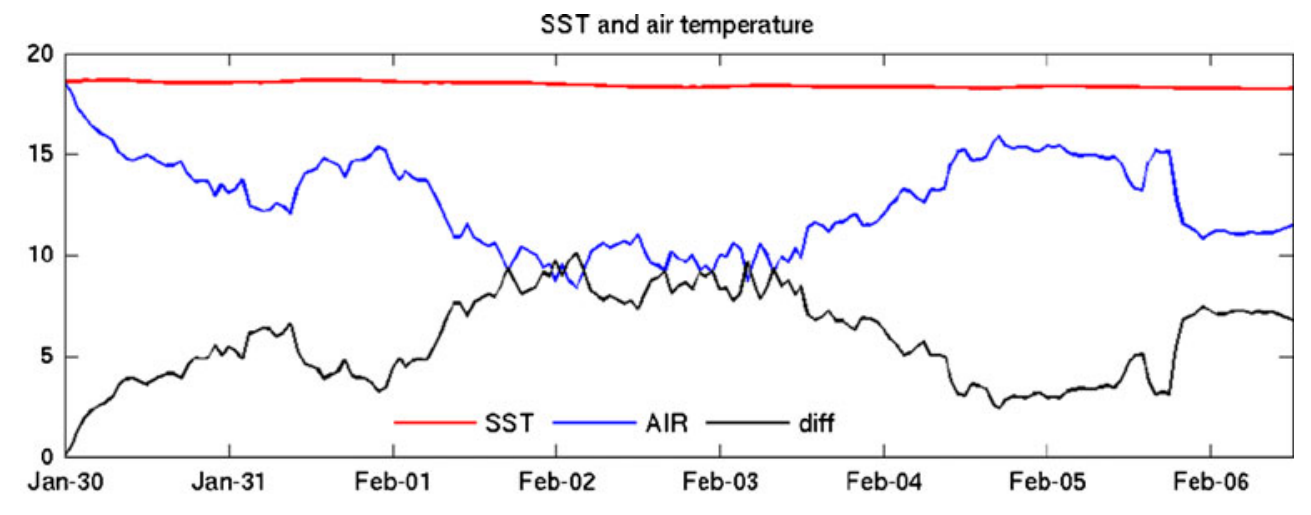

Wind velocity and speed

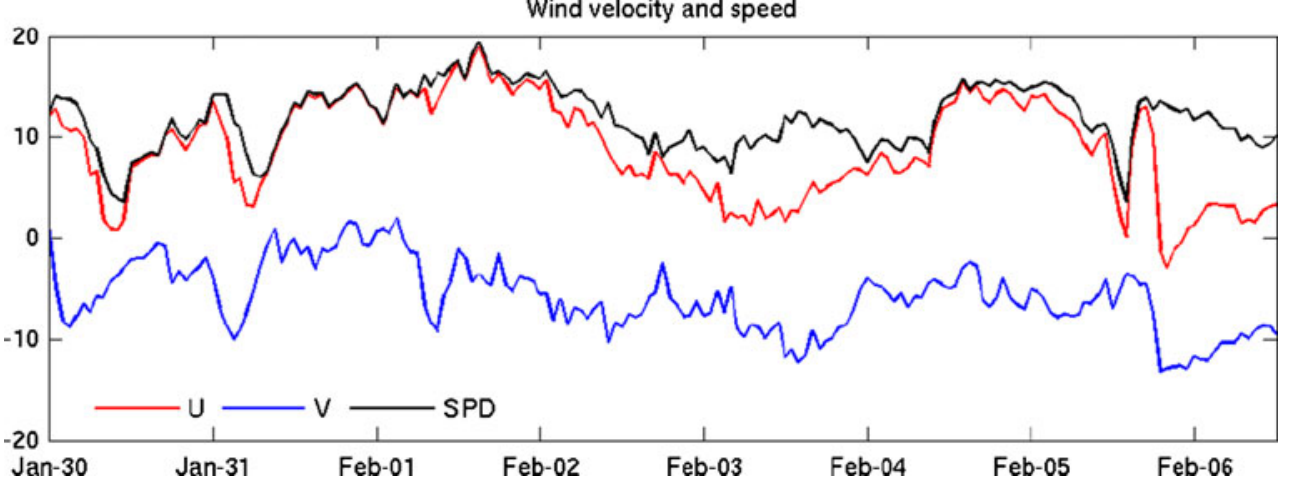


independent data set for model validation. Consequently, it is not surprising that the agreement at the KEO site (Fig. 4) is very good with correlation values around 0.80 . On the other hand, the analysis includes numerous other observations, so a perfect match at a single mooring cannot be assured. There is a bias toward cooler air temperatures and cooler SST (not shown) in the model, while the amplitude of the wind speed is overestimated by nearly $1.7 \mathrm{~m} / \mathrm{s}$. The bias for the individual wind components is larger (Fig. 4).

\subsection{Comparison of surface winds with QuikSCAT}

During the first phase of the event, maximum winds are found in the region south of Hokkaido with a cold front extending northward from $32^{\circ} \mathrm{N}$ at $160^{\circ} \mathrm{E}$. Maximum wind speeds are in $20-25 \mathrm{~m} / \mathrm{s}$ range southeast of Hokkaido in the COAMPS5 simulation (Fig. 5, left). The maximum winds measured by QuikSCAT (Fig. 5, right) are slightly stronger than the model winds, but in general in very good agreement with COAMPS5. The locations of the two main fronts are indicated by strong shear and convergence poleward of $32^{\circ} \mathrm{N}$ at $160^{\circ} \mathrm{E}$ for the cold front and eastward of $160^{\circ} \mathrm{E}$ for the warm front.

On 1 February, the maximum wind speeds had increased to be in the excess of $30 \mathrm{~m} / \mathrm{s}$ and were centered near $30^{\circ} \mathrm{N}$. The high winds were associated with the rapid formation of a low pressure near $36^{\circ} \mathrm{N}, 155^{\circ} \mathrm{E}$. The QuikSCAT winds are stronger than the COAMPS5 simulation (Fig. 5), in particular, in the frontal zone from $35^{\circ} \mathrm{N}$ to $50^{\circ} \mathrm{N}$ centered near $170^{\circ} \mathrm{E}$.
Fig. 4 Hourly output of 2-m air temperature and $10-\mathrm{m}$ wind components from COAMPS5 at the KEO buoy location and from the KEO buoy observations (black line). The model results are from the $3-\mathrm{km}$ atmospheric grid. The blue line shows the solution from the fully coupled model and the red line from the model run forced by NCODA SST (from Allard et al. 2010b)

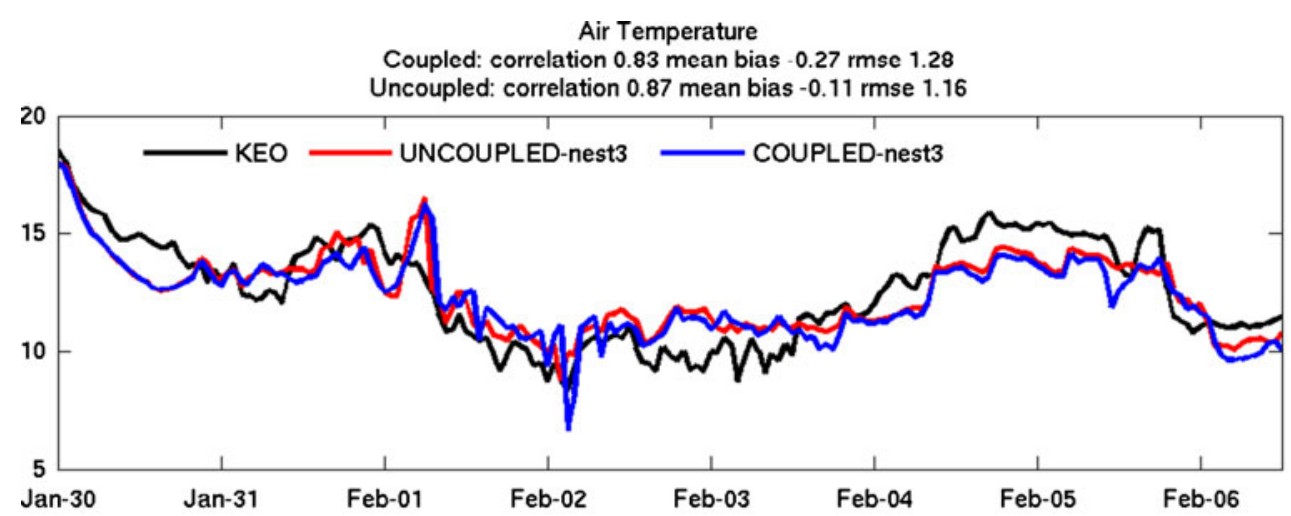

Zonal Wind

Coupled: correlation 0.75 mean bias 3.07 rmse 4.56 Uncoupled: correlation 0.70 mean bias $3.31 \mathrm{rmse} 4.87$

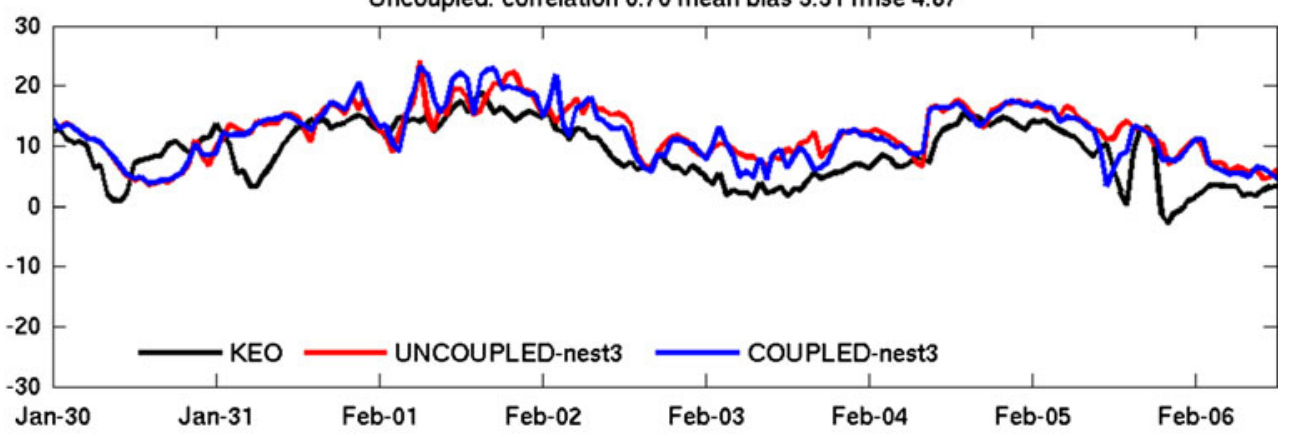

Meridional Wind

Coupled: correlation 0.77 mean bias 2.33 rmse 3.79

Uncoupled: correlation 0.73 mean bias 1.97 rmse 3.68

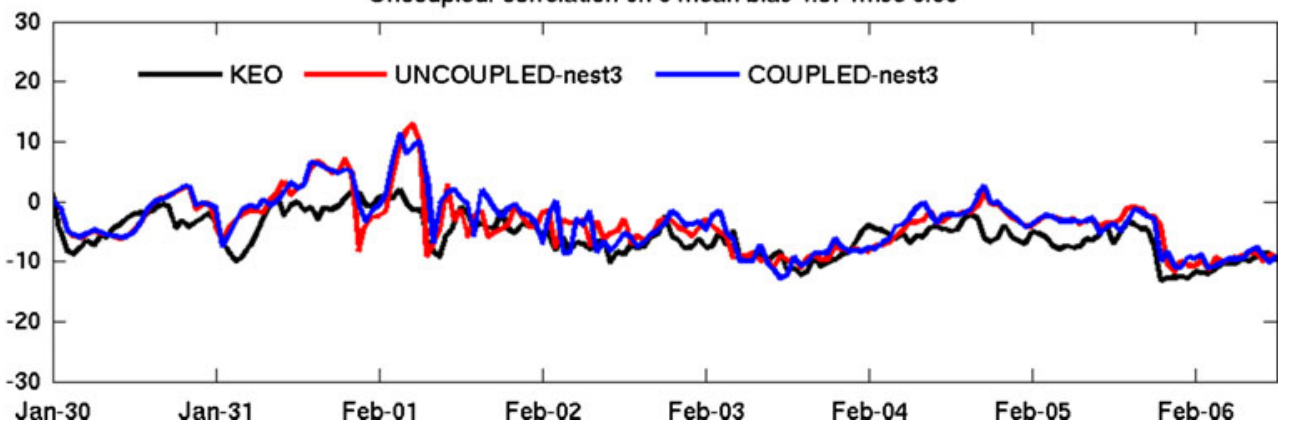



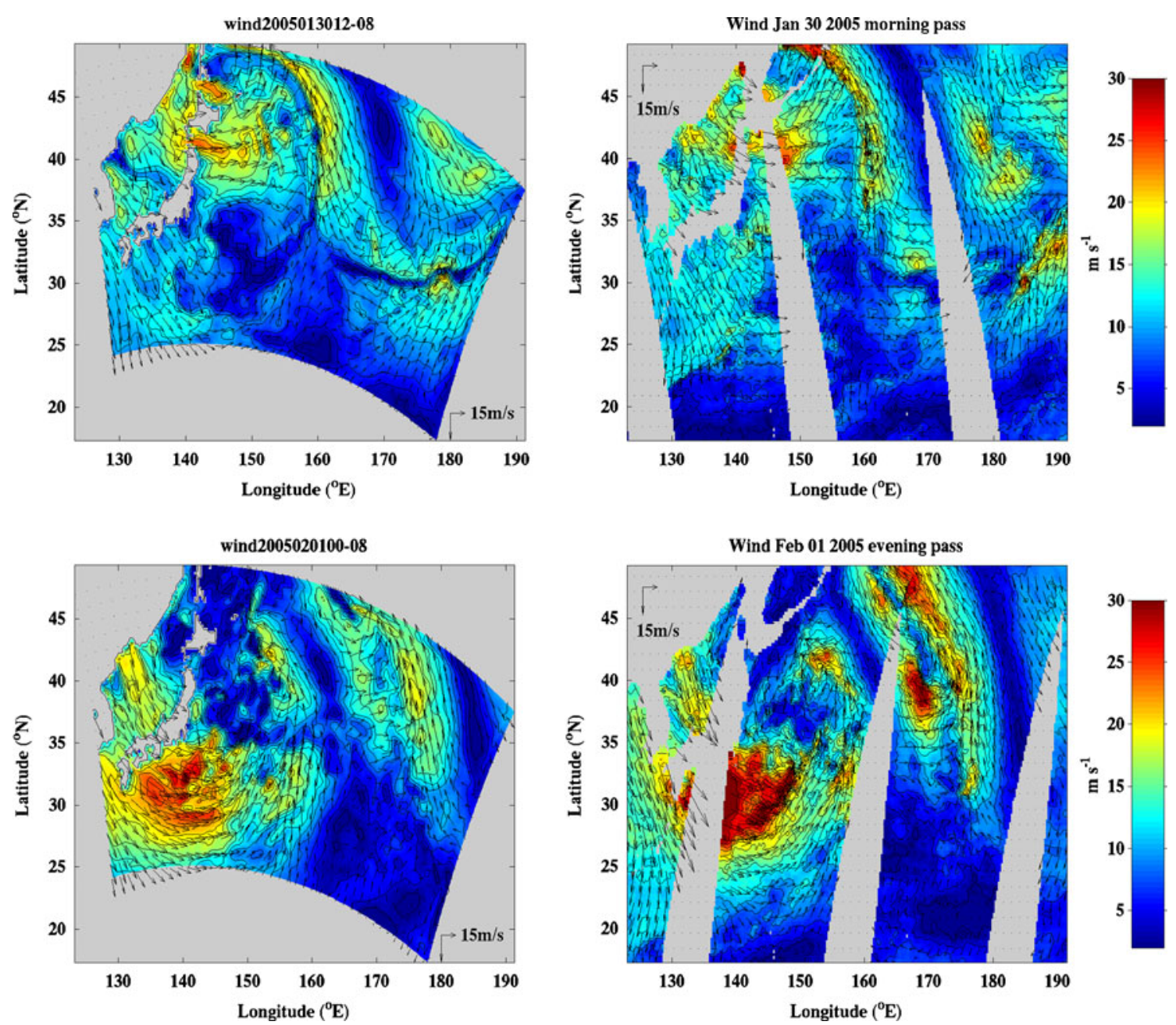

Fig. 5 Wind at $10 \mathrm{~m}$ from the 27-km COAMPS5 model (left panels) forecasts for 30 January 2000 UTC (left, top), and 1 February 800 UTC (left, bottom). The forecast was initialized at 0000 UTC.

QuikSCAT winds from the corresponding times are shown in the right panels: ascending pass on 30 January is shown on top right and descending pass on 1 February is shown in the right bottom panel

\subsection{Comparison of COAMPS5 results to objectively} analyzed turbulent heat fluxes

In January 2008, Woods Hole Oceanographic Institution provided Objectively Analyzed Air-Sea Fluxes (OAFlux) to the scientific community. The analysis includes global analyses of sensible and latent heat fluxes on a $1^{\circ} \times 1^{\circ}$ grid with monthly fields from 1958 to 1984 and daily fields from 1985 to 2006 (Yu and Weller 2007; Yu et al. 2008).

Daily means of sensible and latent heat flux were computed from hourly output from COAMPS5 and for the OAFlux data set. Figure 6, top panels, show the sensible heat flux, Fig. 6, middle panels show the latent heat flux, while the bottom panels show the sum of those two quantities from the coupled COAMPS5 and OAFlux.

The observed daily sensible heat flux from OAFlux has a maximum of $560 \mathrm{~W} / \mathrm{m}^{2}$, slightly higher than found in COAMPS5. The uncoupled run (not shown) has fluxes up to $526 \mathrm{~W} / \mathrm{m}^{2}$, while the coupled run has a maximum of $514 \mathrm{~W} / \mathrm{m}^{2}$. Note that both the coupled run and the observed sensible heat flux have two distinct maxima, while the uncoupled run (not shown) only has a single maximum. The coupled run solution has much more small-scale features than the uncoupled run because of small-scale features in the model SST field. The reason for the smaller sensible heat flux in COAMPS5 compared with OAFlux values is not clear. At the KEO buoy, the air-sea temperature difference is about 0.7 deg smaller on average in COAMPS5 simulations than observed, which would tend to underestimate the sensible heat flux. The difference is mainly due to differences in SST rather than in air temperature. However, in the model, the KEO site is closer to the center of a cyclonic cold core eddy than it appears to be in the real ocean judging from Topex/Poseidon data, so the average SST bias for the region overall is likely to be smaller than at the KEO site. 

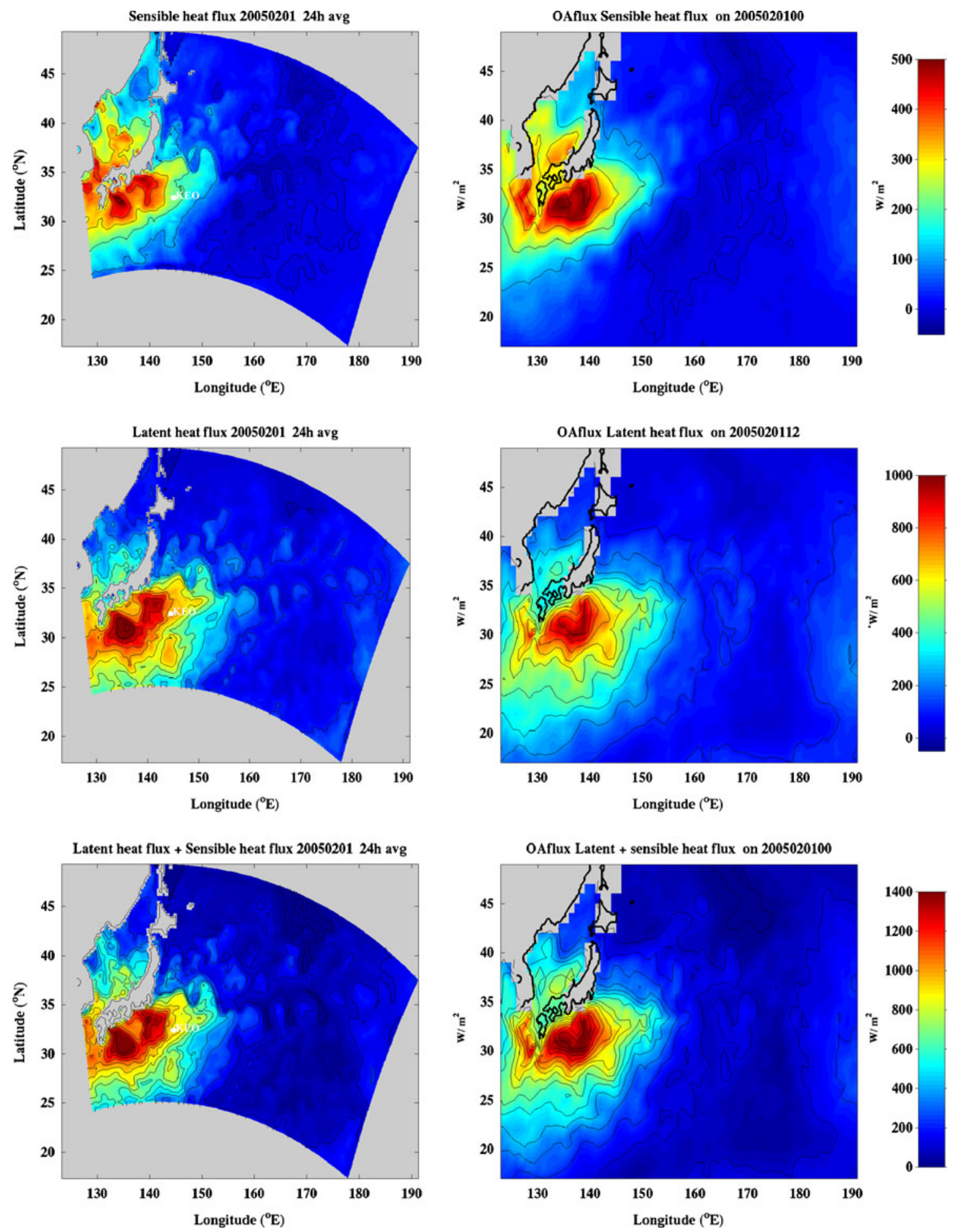

Fig. 6 Sensible heat flux (top), latent heat flux (middle), and their sum (bottom) from the fully coupled COAMPS5 on the $27 \mathrm{~km}$ grid (left) and the $\mathrm{Yu}$ and Weller synthesis (right). The results are from a $24 \mathrm{~h}$ average on 1 February 2005

The maximum latent heat flux from the objective analysis is $995 \mathrm{~W} / \mathrm{m}^{2}$ for 1 February. The model fluxes are about $10 \%$ higher, with 1,080 and $1,122 \mathrm{~W} / \mathrm{m}^{2}$ for the uncoupled run and the coupled run, respectively. There is a slightly better agreement between the OAFlux analysis and the coupled run compared with the uncoupled run (not shown). For instance, in the Sea of Japan, the uncoupled run has a smaller latent heat flux and the local minimum in 
heat flux off the southern coast of Japan near $32^{\circ} \mathrm{N}$ is much less pronounced in the uncoupled case.

The reason for the larger latent heat flux in COAMPS5 compared with the OAFLUX synthesis is likely that the air in the atmospheric boundary layer is too dry in the model. During the simulation, the relative humidity at the KEO buoy is $72 \%$ versus $57 \%$ in COAMPS5. Neither the dry bias nor the cold SST are systematic errors in COAMPS5. In other simulations, the biases are different.

The total heat flux by turbulent transfer (Fig. 6, bottom panels) is the sum of the sensible and latent heat fluxes. Overall the agreement between model and observations is very good. The maximum flux in the uncoupled model is 1,576 and $1,584 \mathrm{~W} / \mathrm{m}^{2}$ for the coupled run. In comparison, the analysis has a maximum of $1,520 \mathrm{~W} / \mathrm{m}^{2}$. This is an excellent agreement considering the extreme nature of the event. It also gives confidence in the model forecast.

3.5 Detailed development of the cold-air outbreak event from the COAMPS5 simulation

The overall good agreement between COAMPS5 and observed meteorological conditions in the previous section provides confidence in the coupled models ability to simulate the event and give insight in the physical processes involved in more detail.

\subsection{Ocean conditions in the Kuroshio Extension region}

During January and February 2005, the Kuroshio was in a stable recirculation pattern, as defined by Qiu and Chen (2005), in the extension region. The transition to an unstable circulation mode did not take place until the fall of 2005 (Qiu et al. 2007). South of the main Kuroshio path, the recirculation is maintained by two cyclonic quasistationary cold core rings. Sea surface heights from Topex/ Poseidon reveal that the two rings existed from early January 2005 until August 2005 (Qiu et al. 2007; see their Fig. 2). This general pattern does not change much during the event, but the large meander between $148^{\circ} \mathrm{E}$ and $153^{\circ} \mathrm{E}$ becomes steeper and shreds warm core filaments, and the region occupied by the two cold core rings and the cyclonic circulation cools and covers a larger area after the cold-air outbreak (Fig. 7). Current variability in the model is dominated by tides that modulate the strength of the Kuroshio jet and the recirculation.

\section{Air-sea interaction and impact on the ocean}

\subsection{Evolution of surface wind field}

The good agreement between model and satellite wind gives confidence in the surface winds in the coupled model. Figure 8 shows 12 -h winds at $10 \mathrm{~m}$ from 30 January 0000 UTC to 4 February 1200 UTC. The first $36 \mathrm{~h}$ are dominated by the eastward propagating cold front in the northern part of the domain, with the warmer air blowing poleward to the east. A new low pressure, formed by 1 February 1200 UTC, leads to the strong westerly surface winds over the subtropical warm pool region as seen in the QuikSCAT observations (Fig. 5). The strong westerly winds spread eastward and dominate the entire area to $170^{\circ} \mathrm{E}$ by 4 February 1200 UTC.

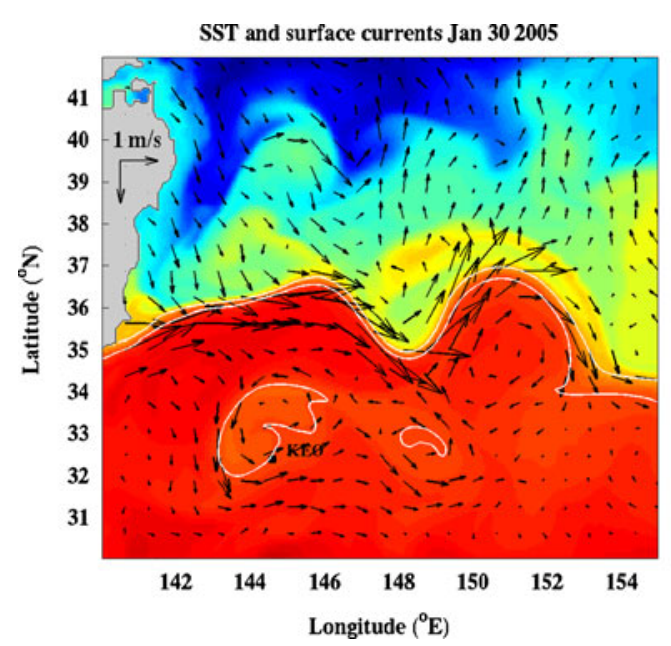

Fig. 7 Initial SST and surface currents for 30 January 0000 UTC (left) and the hindcast for 6 January 0000 UTC (right) on the COAMPS5 1/ $16^{\circ}$ ocean model grid. The initial condition (left) has been interpolated to the coupled ocean model grid from the EAS16 model. White

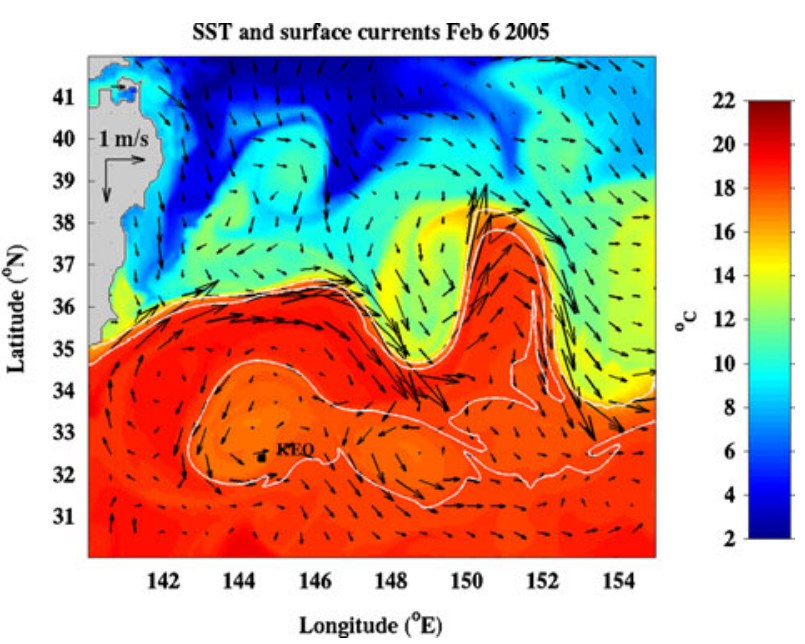

contours show the $16^{\circ} \mathrm{C}$ and $18^{\circ} \mathrm{C}$ isotherms. Only every tenth current vector in each direction is shown. The KEO buoy location is marked by a black square 

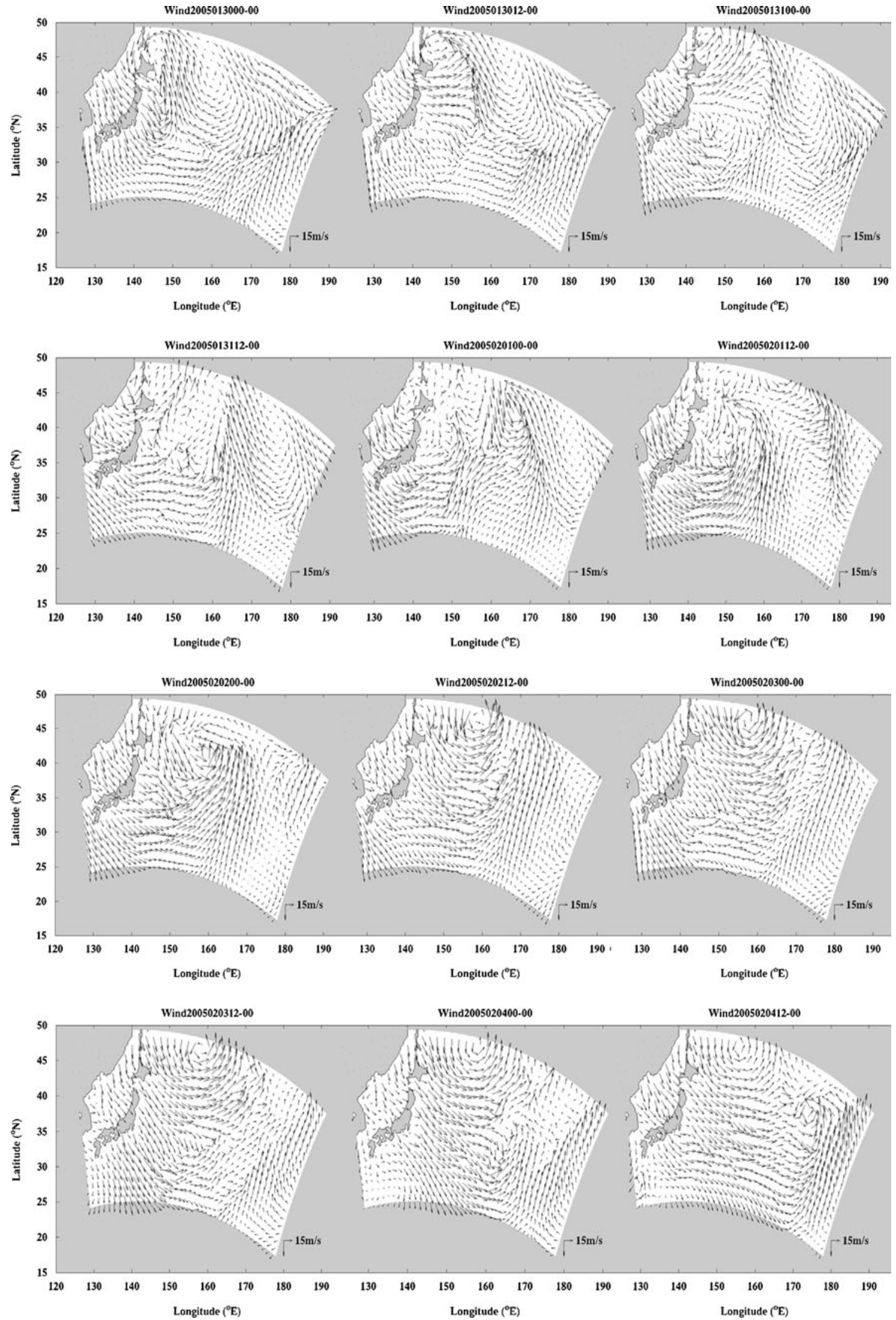

Fig. 8 Wind at $10 \mathrm{~m}$ from COAMPS5 on the $27 \mathrm{~km}$ grid for the analysis at 12-h interval for 30 January 0000 UTC (upper left) to 4 February 1200 UTC 2005 (lower right) 


\subsection{Air-sea temperature differences}

The turbulent heat fluxes are enhanced by strong winds. Sensible heat flux is proportional to the difference in temperature between the ocean and the atmosphere, and latent heat flux is proportional to the difference between the actual water vapor pressure and the saturated vapor pressure. During cold-air outbreaks, the continental air has a temperature well below the freezing point and as a result, contains very little moisture. When advected over the ocean, sensible heat warms the air near the ocean surface making it relatively dry compared with saturated air, resulting in large latent heat fluxes. Figure 9 shows the temperature difference between the 2-m level in the air and the sea surface on the atmospheric $27 \mathrm{~km}$ grid every $12 \mathrm{~h}$ starting at 30 January 0000 UTC. As seen from the wind field (Fig. 8), the negative air-sea temperature differences are due to advection of continental air over the Sea of Japan and progressing over the Northwest Pacific. Warm subtropical air is advected poleward along the front, resulting in positive air-sea anomalies east of $160^{\circ} \mathrm{E}$. The strong positive anomaly north of Hokkaido is due to sea ice.

\subsection{Evolution of turbulent heat fluxes}

Figure 10 shows the daily averaged latent heat flux and Fig. 11 shows the daily averaged sensible heat flux on the 9-km atmospheric grid from 30 January to 6 February 2005 as well as the average fluxes during that time (lower right panel in both figures). Strong winds near Hokkaido (Fig. 5 top panels and Fig. 8, first panel) on 30 January results in large sensible and latent heat fluxes, but only last a day since the air-sea temperature differences decrease rapidly over the already cold water. On 31 January, the core of strong winds has shifted south to $32^{\circ} \mathrm{N}$ to be located over the subtropical warm water resulting in airsea differences of up to $12^{\circ} \mathrm{C}$ (Fig. 9). Total turbulent heat fluxes up to $2,300 \mathrm{~W} / \mathrm{m}^{2}$ for hourly means were found during 1 February. From 2 February until the end of the simulation, maximum heat fluxes are found in the areas where two meanders of warm subtropical water protrudes to the north and on the south side of the Kuroshio front. The southern flank of the Kuroshio was also indentified as the location of intense sensible and latent heat fluxes in the study of Tokinaga et al. (2009). The variation in heat flux is primarily due to changes in wind speed (Fig. 8) rather than air-sea temperature differences (Fig. 9). The sensible and latent heat fluxes are fairly well correlated with a ratio of sensible heat flux to latent heat flux (Bowen ratio) in the range of $0.2-0.4$ with the lowest values over subtropical water and the higher values over cold water. As noted from Fig. 7, the SST pattern change is small during the event, and it is clear from Figs. 10 and 11 that strong SST gradients results in strong turbulent heat flux gradients.

\subsection{Area-averaged heat fluxes}

Different areas are subject to large differences in turbulent heat fluxes (Figs. 10 and 11). In order to quantify these differences, averages were computed by dividing up the model region in three area classes based for on SST: Cold water area for $\mathrm{SST}<16^{\circ} \mathrm{C}$, mode water area for $16^{\circ}<\mathrm{SST}<19^{\circ} \mathrm{C}$, and warm water with $\mathrm{SST}>19^{\circ} \mathrm{C}$. Figure 12 shows the hourly area integrated components of latent heat flux, sensible heat flux, solar heat flux, and net long-wave radiation for the three classes. The average heat flux is shown in Table 1 below.

The latent heat flux over the warm subtropical water is nearly twice the flux over the mode water with maximum near $600 \mathrm{~W} / \mathrm{m}^{2}$ over the region on 1 February between 60 and $70 \mathrm{~h}$ after the start of the simulation and remains above $300 \mathrm{~W} / \mathrm{m}^{2}$ throughout the rest of the model run. The temporal change in area-averaged sensible heat flux for the warm water is similar to that of the latent heat flux, but only a factor 1.3 larger than the other two regions. The net outgoing long-wave radiation is nearly constant during the simulation. The daily maximum solar flux is smallest on Feb 1 with $250 \mathrm{~W} /$ $\mathrm{m}^{2}$ due to clouds associated with cloudiness at the cold front. Over the warm water, which is located closer to the equator, the average daily maximum reached $504 \mathrm{~W} / \mathrm{m}^{2}$ on 5 February $(170 \mathrm{~h})$.

\subsection{Formation of core layer North Pacific Subtropical Mode Water}

The cooling event leads to formation of NPSTMW. Our coupled model region is limited to a part of the NPSTMW formation area, but includes the entire recirculation gyre where the core layer of NPSTMW is formed under winter time conditions. We therefore adopt the range given in Hanawa and Suga (1995) for the typical core layer NPSTMW water properties: $16^{\circ} \mathrm{C}-18^{\circ} \mathrm{C}$ and 34.75 $34.85 \mathrm{psu}$, which is identical to the temperature range used by Qiu et al. (2006) for the Kuroshio recirculation region. Their salinity range was slightly larger with a lower limit at 34.70 psu.

Figure 13 shows a meridional cross-section of the daily mean of potential temperature in the upper $600 \mathrm{~m}$ of the ocean along $144^{\circ} \mathrm{E}$ on 30 January 2005 (Fig. 13, top) before the cold-air outbreak and after the event (Fig. 13, bottom) on 6 February. The core layer of the mode water has increased its surface manifestation with an apparent increase in volume. The total volume was computed for 
this water mass between $140^{\circ} \mathrm{E}$ and $155^{\circ} \mathrm{E}$ from $30^{\circ} \mathrm{N}$ to $39^{\circ} \mathrm{N}$ and is shown in Fig 14 during the event. The rate of core layer mode water formation is $12.8 \mathrm{~Sv}$ on average, leading to an increase in core mode water volume of about
$10 \%$ over the model region. However, the rate of transformation is sensitive to the definition used for NPSTMW. From Fig. 14, it is seen that the change in core layer volume is $1 \times 10^{13} \mathrm{~m}^{3}$, which is about $10 \%$ of the
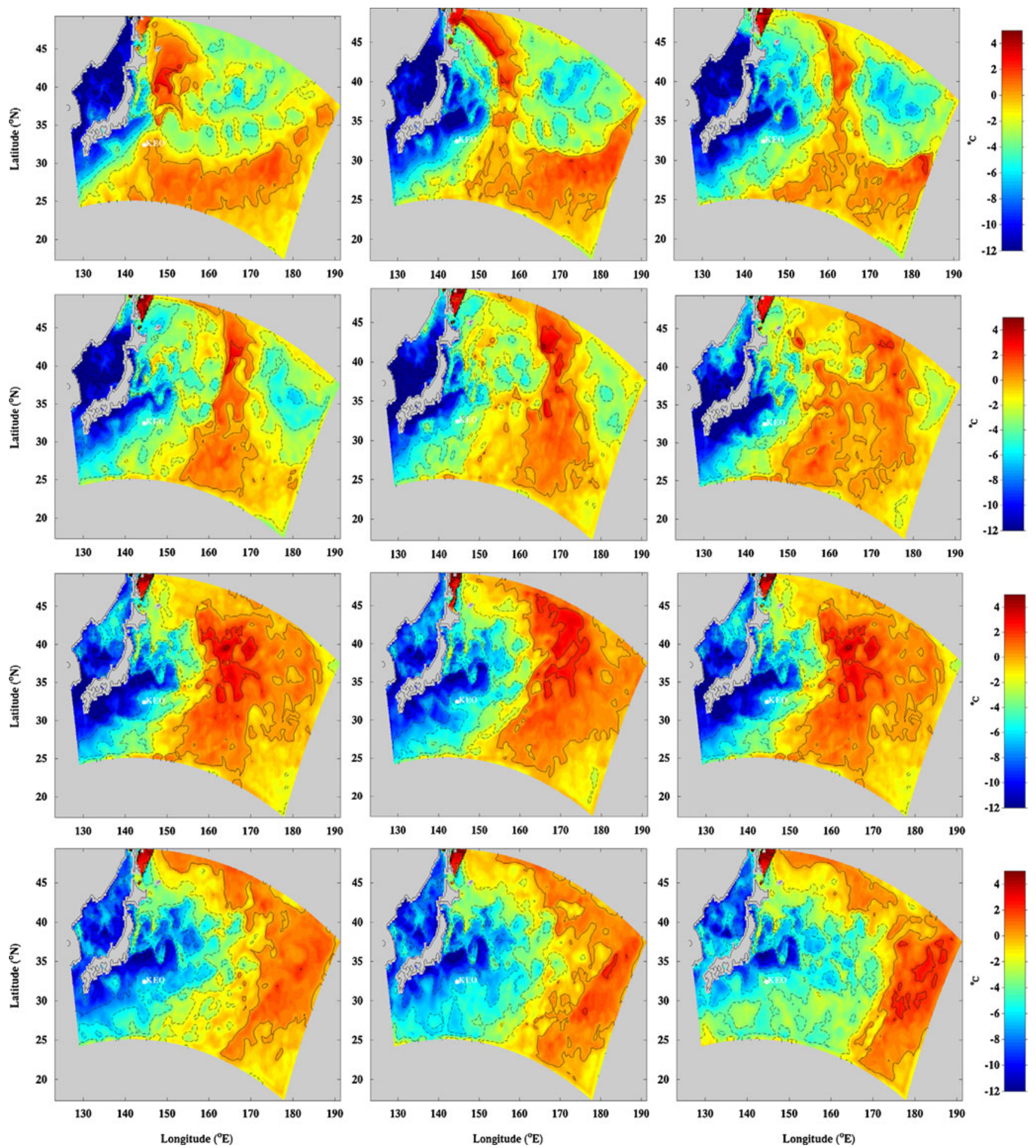

Fig. 9 Air temperature at $2 \mathrm{~m}$ minus SST on the $27 \mathrm{~km}$ grid for forecast for 30 January 0000 UTC (upper, left) through 4 February 1200 UTC (lower, right). Time is increasing left to right, then downward with an increment of $12 \mathrm{~h}$ 

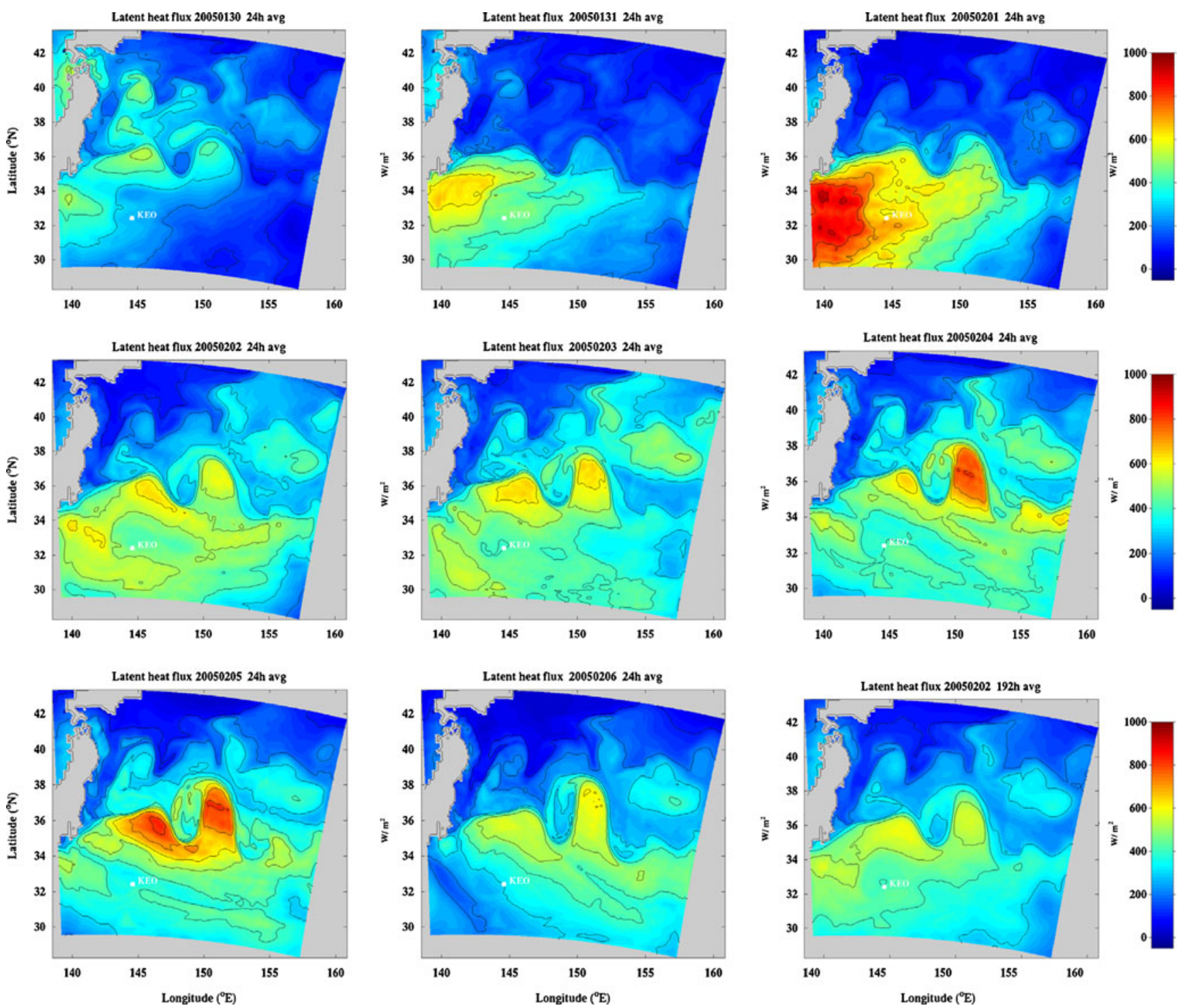

Fig. 10 Daily average of latent heat flux from 30 January 2005 (upper, left) through 6 February 2005 (lower middle panel). Time is increasing left to right, then downward with an increment of 1 day.
The panel in the lower right shows the average latent heat flux during the $192 \mathrm{~h}$ from 30 January 00 UTC until 7 February 0000 UTC. Units are in watts per square meter annual formation rate of NPSTMW calculated from the model study by Rainville et al. (2007).

The two cold core rings at $33^{\circ} \mathrm{N}$ provide a direct connection from the core of the mode water to the atmosphere (Figs. 7 and 13), and the area of this "window" is clearly increased as a consequence of the event. Using the temperature and salinity ranges above to define mode water, the surface area of the NPSTMW core layer that is exposed to the atmosphere increased from 40,000 to $190,000 \mathrm{~km}^{2}$ during the cold-air outbreak (Fig. 15). The new mode water formation takes place within the area occupied by the cyclonic cold core rings (Fig. 7). The expanded mode water volume and surface area is also apparent in the cross-section given in Fig. 13.

\section{Summary and discussion}

The coupled atmosphere-ocean modeling system COAMPS5 was configured for the Kuroshio Extension region using multiple one-way nested high-resolution grids and fully coupled with a 12-min coupling interval. The ability to produce a simulation consistent with marine meteorology from buoy data and scatterometer surface winds during a rapidly developing and strong cold-air outbreak was demonstrated. During the 30 January to 7 February 2005 simulation, cold continental air was first advected from the Asian continent over the cold waters in the vicinity of Hokkaido, with a second cold phase to the south over the warm subtropical waters. 

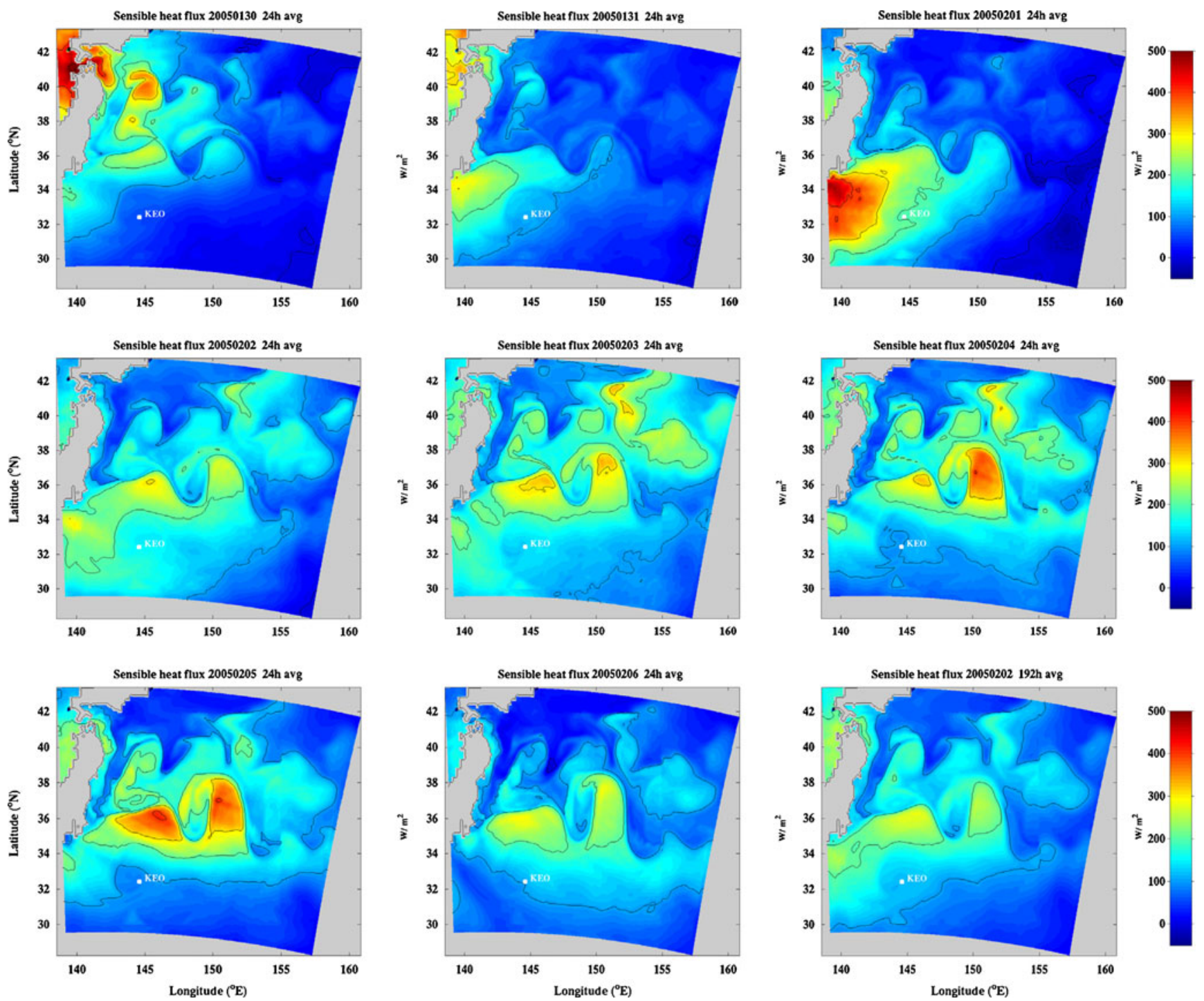

Fig. 11 Daily average of sensible heat flux from 30 January (upper, left) through 6 February (lower middle panel). Time is increasing left to right, then downward with an increment of 1 day. The panel in the lower right shows the average sensible heat flux during the $192 \mathrm{~h}$ from 30 Jan 0000 UTC until 7 February 0000 UTC. Units are in watts per square meter
The latter cold front leads to daily average sensible heat fluxes and latent heat fluxes in excess of 500 and $1,500 \mathrm{~W} / \mathrm{m}^{2}$, respectively. The maximum combined instantaneous turbulent heat flux found in the model simulation was $2,300 \mathrm{~W} / \mathrm{m}^{2}$. The largest heat fluxes were found in two large meanders of the Kuroshio and in the area just south of the oceanic jet. The maximum values of turbulent heat fluxes reported in this study are extremely large but similar to those found in the $\mathrm{Yu}$ and Weller (2007) synthesis and maximum values from earlier studies. For instance, Huang and Raman (1990) found maximum values of $400 \mathrm{Wm}^{-2}$ for sensible heat flux and
$1,400 \mathrm{Wm}^{-2}$ for latent heat flux in their model study of cold-air flow over the Gulf Stream using fixed SSTs. On the other hand, it should be cautioned that Moore and Renfrew (2002) have shown that many bulk formulations used in models and re-analyses overestimate turbulent heat fluxes, in particular, in cases of large air-sea temperature differences and high winds.

Using a three-dimensional model with high resolution allows very strong SST gradients, and very strong gradients in turbulent heat fluxes were maintained during the model simulation, which may lead to the occurrence of larger turbulent heat flux maxima than models with coarser 
Fig. 12 COAMPS5 hourly area averages latent heat flux (dots), sensible heat flux (solid), solar radiation (chain-dot), and net long-wave radiation (dash) from 0 to $192 \mathrm{~h}$ (30 January 0000 UTC to 7 February 0000 UTC). The top panel shows the heat flux components over water warmer than $19^{\circ} \mathrm{C}$.

The middle panel shows the heat flux over mode water $\left(16^{\circ} \mathrm{C}<\mathrm{SST}<19^{\circ} \mathrm{C}\right)$ and bottom panel shows the heat fluxes for water colder than $16^{\circ} \mathrm{C}$. Units are in watts per square meter

Table 1 Average heat flux contributions into the ocean over cold water, mode water, and warm water

\section{Heat fluxes over warm water}

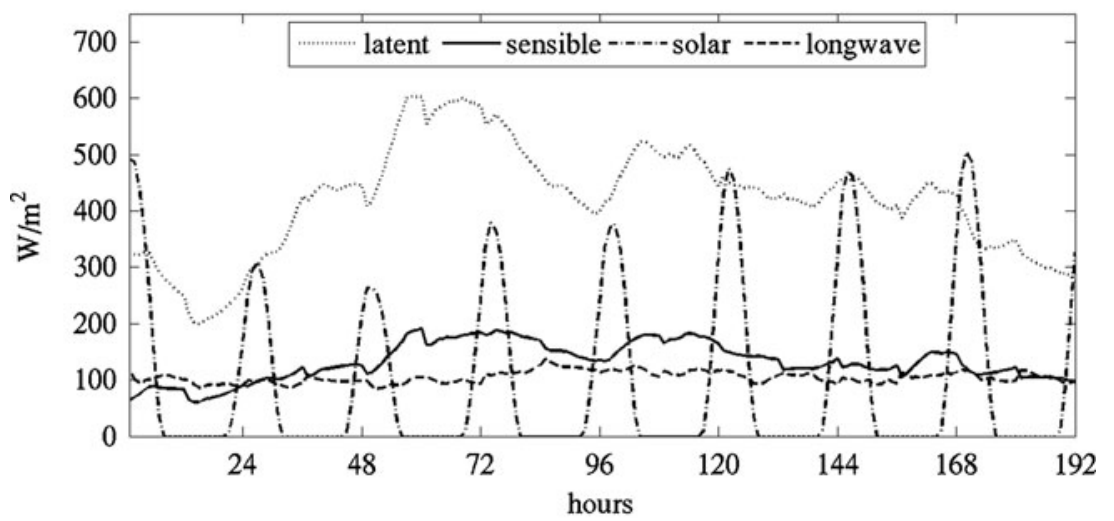

Heat fluxes over core layer mode water

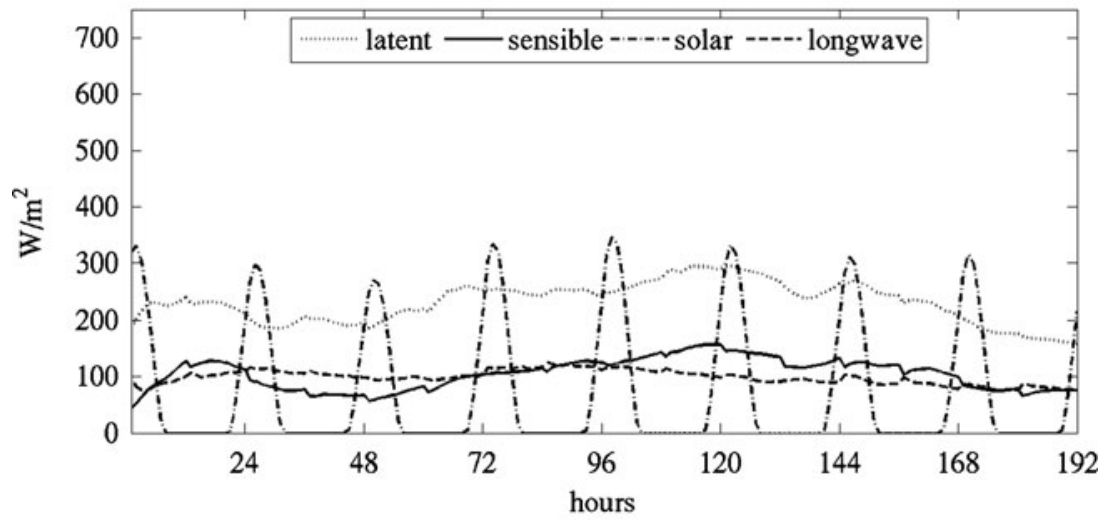

Heat fluxes over cold water

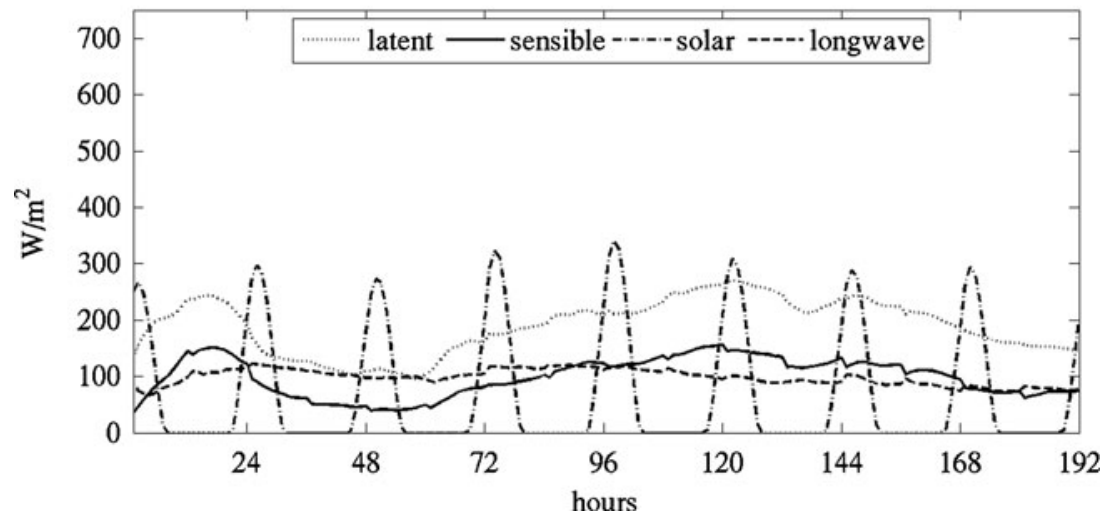

\begin{tabular}{lccc}
\hline Water class & Cold water & Mode water & Warm water \\
\hline Latent heat flux $\left(\mathrm{W} / \mathrm{m}^{2}\right)$ & -188.9 & -231.8 & -418.7 \\
Sensible heat flux $\left(\mathrm{W} / \mathrm{m}^{2}\right)$ & -98.3 & -104.6 & -131.8 \\
Solar heat flux $\left(\mathrm{W} / \mathrm{m}^{2}\right)$ & 71.8 & 76.8 & 102.7 \\
Long-wave heat flux $\left(\mathrm{W} / \mathrm{m}^{2}\right)$ & -98.2 & -98.6 & -104.4 \\
\hline
\end{tabular}


Fig. 13 Potential temperature cross-sections along $144^{\circ} \mathrm{E}$ on 30 January 2005 (top) and on 6 February 2005 (bottom). The two contours show the boundaries of the core layer of NPSTMW defined to be between $16^{\circ} \mathrm{C}$ and $18^{\circ} \mathrm{C}$.

A 24-h average was used.

Unit is in degrees Centigrade
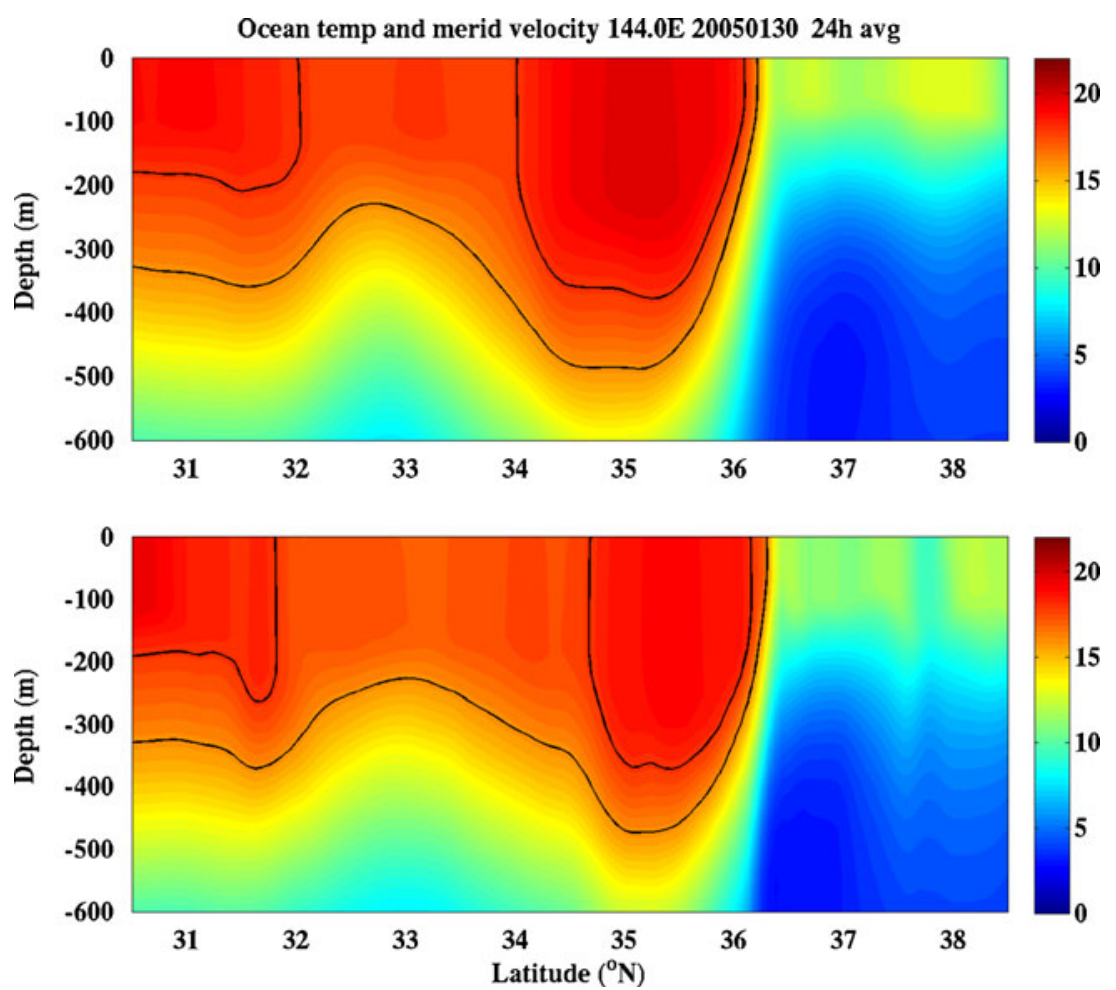

resolution. The largest turbulent heat fluxes are found over water warmer than $18^{\circ} \mathrm{C}$, leading to significant subtropical mode water formation, in particular in the cyclonic recirculation region south of the Kuroshio. Our analysis suggests that a strong cold-air outbreak event can produce core layer North Pacific Subtropical Mode water formation at a rate of $10 \mathrm{~Sv}$ or more during a week-long period. While

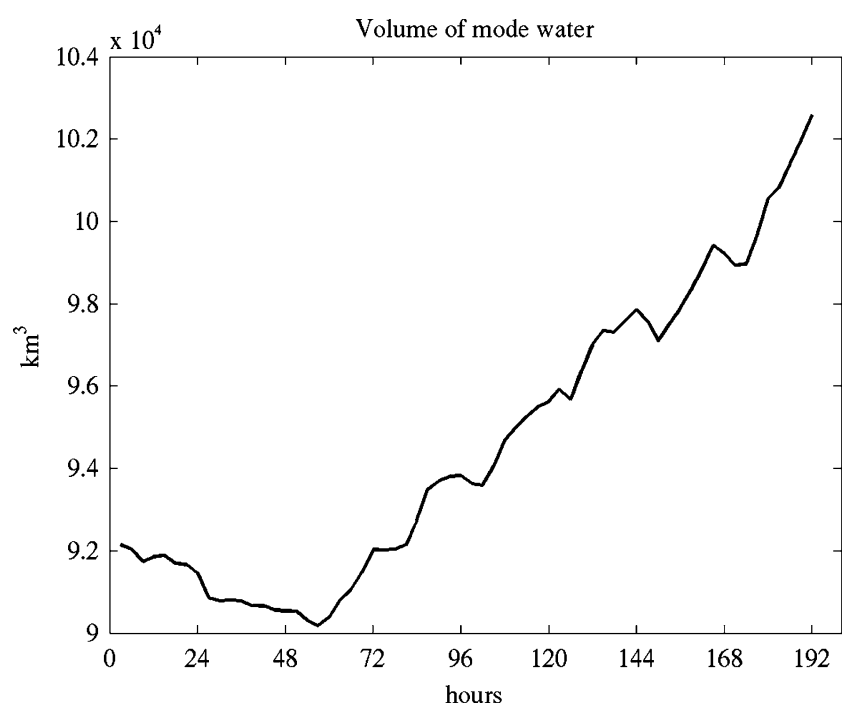

Fig. 14 Variation of volume of North Pacific Subtropical Mode Water between 30 January 2005 at 0000 UTC $(0 \mathrm{~h})$ and 7 February 2005 at $0000 \mathrm{UTC}(192 \mathrm{~h})$ in the region limited by $140^{\circ} \mathrm{E}$ to $155^{\circ} \mathrm{E}$ and $30^{\circ} \mathrm{N}$ to $39^{\circ} \mathrm{N}$. The mode water temperature range is $16^{\circ} \mathrm{C}-18^{\circ} \mathrm{C}$, and salinity is in the range 34.75 to 34.85 psu. The unit for the volume is cubic kilometers our study focused on a single event, it is the cumulative effects of cold-air outbreaks that are of interest for climate time scales, and inter-annual variability of NPSTMW is likely linked to the frequency of cold-air outbreaks. Dorman et al. (2004) give a range of five to 19 cold-air events each winter during the decade from 1991 to 2002, so the occurrence or absence of an outbreak event of comparable

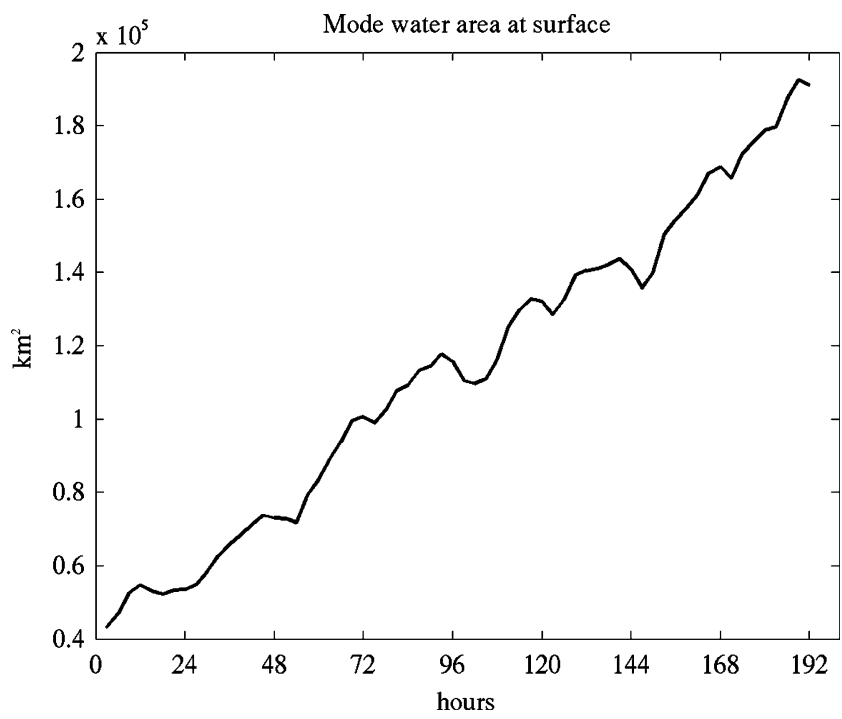

Fig. 15 Variation of surface area of North Pacific Subtropical Mode Water between 30 January 20050000 UTC $(0 \mathrm{~h})$ and 7 February 2005 $0000 \mathrm{UTC}(192 \mathrm{~h})$ in the region limited by $140^{\circ} \mathrm{E}$ to $155^{\circ} \mathrm{E}$ and $30^{\circ} \mathrm{N}$ to $39^{\circ} \mathrm{N}$. The mode water temperature range is $16^{\circ} \mathrm{C}-18^{\circ} \mathrm{C}$, and salinity is in the range 34.75 to 34.85 psu. The unit for area is square kilometers 
magnitude to the case presented in this study will have a significant impact on year to year mode water variability.

Acknowledgments This work was supported by the High Performance Computing Modernization Program's Battlespace Environment Institute and NRL's 6.2 Core Program "Coupled Ocean-Wave Prediction System" (Program Element PE 0602435N). We thank Clark Rowley, Lucy Smedstad, Shelley Riedlinger, and James Dykes at NRL Stennis Space Center for their assistance with providing data for boundary and initial conditions.

\section{References}

Allard R, Campbell T, Chen S, Cook J, Jensen T, Martin P, Rogers E, Small J, Smith T (2010a) The Navy's coupled atmosphereocean-wave prediction system. Proceedings of the OCEANS 2010 MTS/IEEE SEATTLE Conference and Exhibition, Seattle, p 10

Allard RA, Campbell TJ, Smith TA, Jensen TG, Cummings JA, Chen S, Doyle J, Hong X, Small RJ, Carroll, SN (2010b) Validation test report for the Coupled Ocean Atmospheric Mesoscale Prediction system (COAMPS) Version 5.0. NRL/MR/7320-109283, p 160

Barker E (1992) Design of the navy's multivariate optimum interpolation analysis system. Weather Forecast 7:220-231

Barron CN, Birol Kara A, Martin PJ, Rhodes RC, Smedstad LF (2006) Formulation, implementation and examination of vertical coordinate choices in the Global Navy Coastal Ocean Model (NCOM). Ocean Model 11:347-375

Bingham FM (1992) Formation and spreading of Subtropical Mode Water in the North Pacific. J Geophys Res 97:11,177-11,189

Blumberg AF, Mellor GL (1987) A description of a three-dimensional coastal ocean circulation model. In: Heaps $\mathrm{N}$ (ed) Threedimensional coastal ocean models, American Geophysical Union, New York, pp 347-375

Bond NA, Cronin MF (2008) Regional weather patterns during anomalous air-sea fluxes at the Kuroshio Extension Observatory (KEO). J Climate 21:1680-1697

Chen S, Cummings J, Doyle J, Hodur R, Holt T, Liou C-S, Liu M, Mirin A, Ridout J, Schmidt J, Sugiyama G, Thompson WT (2003) COAMPS Version 3 model description - general theory and equations, NRL/PU/7500-03-448, p 143

Cummings JA (2005) Operational multivariate ocean data assimilation. Q J R Meteorol Soc Part C 131:3583-3604

Dirks RA, Kuettner JP, Moore JA (1988) Genesis of Atlantic Lows Experiment (GALE): an overview. Bull Am Meteorol Soc 69:148-160

Dorman CE, Beardsley RC, Dashko NA, Friehe CA, Kheilf D, Cho K, Limeburner R, Varlamov SM (2004) Winter marine atmospheric conditions over the Japan Sea. J Geophys Res 109:C12011. doi:10.1029/2001JC001197

Goerss J, Phoebus P (1992) The Navy's operational atmospheric analysis. Weather Forecast 7:232-249

Grossman RL, Betts AK (1990) Air-sea interactions during an extreme cold air outbreak from the eastern coast of the United States. Mon Weather Rev 118:324-342

Hanawa K, Suga T (1995) A review on the subtropical mode water of the North Pacific (NPSTMW). In: Sakai H, Nozaki Y (eds) Biogeochemical processes and ocean flux in the Western Pacific. Terra Scientific Publishing Co, Tokyo, pp 613-627

Hodur RM (1997) The Naval Research Laboratory's Coupled Ocean/ Atmosphere Mesoscale Prediction System (COAMPS). Mon Weather Rev 125:1414-1430
Huang C-Y, Raman S (1990) Numerical simulation of cold-air advection over the Appalachian Mountains and the Gulf Stream. Mon Weather Rev 118:343-362

Jensen TG, Campbell T, Smith TA, Small RJ, Allard R (2009) Cold air outbreak over the Kuroshio Extension Region. Proceedings of the OCEANS 09 MTS/IEEE BILOXI Conference \& Exhibition Biloxi, MS, p 4

Kallberg P, Berrisford P, Hoskins B, Simmons A, Uppala S, LamyThepaut S, Hine R (2005) ERA-40 Atlas. ECMWF ERA-Project Rep. Series 19, European Centre for Medium Range Weather Forecasts, Reading, p 199

Konda M, Ichikawa H, Tomita H, Cronin M (2010) Surface heat flux variations across the Kuroshio Extension as observed by surface flux buoys. J Climate 23:5206-5221

Kubota M, Iwabe N, Cronin M, Tomita H (2008) Surface heat fluxes from the NCEP/NCAR and NCEP/DOE reanalyses at the Kuroshio Extension Observatory buoy site. J Geophys Res 113: C02009. doi:10.1029/2007/JC004338

Langland RH, Baker NL (2004) A technical Description of the NAVDAS Adjoint System. NRL/MR/7530-04-8746, Naval Research Laboratory, Monterey, CA

Lenschow DH, Agee EM (1976) Preliminary results from the Air Mass Transformation Experiment (AMTEX). Bull Amer Meteorol Soc 57:1346-1355

Li Y, Xue H, Bane JM (2002) Air-Sea interactions during the passage of a winter storm over the Gulf Stream: a three-dimensional coupled atmosphere-ocean study. J Geophys Res 107: doi:10.1029/2001JC001161

Louis J-F (1979) A parametric model of vertical eddy fluxes in the atmosphere. Bound Layer Meteor 17:187-202

Martin PJ (2000) Description of the Navy Coastal Ocean Model Version 1.0. NRL Report No. NRL/FR/7322/00/9962, p 45. [Available from NRL, Code7322, Bldg. 1009, Stennis Space Center, MS 39529-5004, USA]

Masuzawa J (1969) Subtropical mode water. Deep-Sea Res 16:463472

Mellor GL (1991) An equation of state for numerical models of oceans and estuaries. J Atmos Oceanic Technol 8:609-611

Mellor GL, Yamada T (1982) Development of a turbulence closure model for geophysical fluid problems. Rev Geophys Space Phys 20:851-875

Minobe S, Kuwano-Yoshida A, Komori N, Xie S-P, Small RJ (2008) Influence of the Gulf Stream on the troposphere. Nature 452:206-209. doi:10.1038/nature06690

Moore GWK, Renfrew IA (2002) An assessment of the surface turbulent heat fluxes from the NCEP-NCAR reanalysis over the western boundary currents. J Climate 15:2020-2037

Oka E, Suga T (2003) Formation region of North Pacific subtropical mode water in the late winter of 2003. Geophys Res Lett 30:2205. doi:10.1029/2003GL018581

Qiu B, Chen S (2005) Variability in the Kuroshio Extension jet, recirculation gyre and mesoscale eddies on decadal time scales. J Phys Oceanogr 35:2090-2103

Qiu B, Chen S (2006) Decadal variability in the formation of North Pacific subtropical mode water: oceanic versus atmospheric control. J Phys Oceanogr 36:1751-1762

Qiu B, Chen S, Hacker P (2004) Synoptic-scale air-sea flux forcing in the western North Pacific: observations and their impact on SST and the mixed layer. J Phys Oceanogr 34:2148-2159

Qiu B, Chen S, Hacker P (2007) Effect of Mesoscale eddies on subtropical mode water variability from the Kuroshio Extension System Study (KESS). J Phys Oceanogr 37:982-1000

Qiu B, Hacker P, Chen S, Donohue KA, Watts DR, Mitsudera H, Hogg NG, Jayne SR (2006) Observations of the Subtropical Mode Water evolution from the Kuroshio Extension System Study. J. Phys. Oceanogr 36:457-473 
Rainville L, Jayne SR, McClean JL, Malthud ME (2007) Formation of subtropical mode water in a high-resolution ocean simulation of the Kuroshio Extension region. Ocean Model 17:338-356

Riedlinger S, Preller R, Martin PJ (2006) Validation Test Report for the $1 / 16^{\circ}$ East Asian Seas Navy Coastal Ocean Model Nowcast/ Forecast System. NRL Report No. NRL/MR/7320/06/8978, p 140. [Available from NRL, Code7322, Bldg. 1009, Stennis Space Center, MS 39529-5004, USA]

Sanders F, Gyakum JR (1980) Synoptic-dynamic climatology of the "bomb". Mon Weather Rev 108:1589-1606

Smagorinsky J (1963) General circulation experiments with primitive equations, I. The basic experiment. Mon Weather Rev 91:99-164

Small RJ, de Szoeke SP, Xie S-P, O’Neill L, Seo H, Song Q, Cornillon P, Spall M, Minobe S (2008) Air-sea interaction over fronts and eddies. Dyn Atmos Oceans 45:274-319

Suga T, Hanawa K (1995) The subtropical mode water circulation in the North Pacific. J Phys Oceanogr 25:958-970

Suga T, Hanawa K, Toba Y (1989) Subtropical mode water in the $137^{\circ} \mathrm{E}$ section. J Phys Oceanogr 19:1605-1618

Sun W-Y, Hsu WR (1988) Numerical study of cold air outbreak over the ocean. J Atmos Sci 45:1205-1227

Taguchi B, Nakamura H, Nonaka M, Xie S-P (2009) Influences of the Kuroshio/Oyashio Extensions on air-sea heat exchanges and storm-track activity as revealed in regional atmospheric model simulations for the 1003/2004 cold season. J Climate 22:65366560

Tokinaga H, Tanimoto Y, Xie S-P, Sampe T, Tomita H, Ichikawa H (2009) Ocean frontal effects on the vertical development of clouds over the western North Pacific: in situ and satellite observations. J Climate 22:4241-4260

Xue H, Bane JM, Goodman LM (1995) Modification of the Gulf Stream through strong air-sea interaction in winter: observation and numerical simulations. J Phys Oceanogr 25:533557

Xue H, Pan Z, Bane JM (2000) A 2D coupled atmosphere-ocean model study of air-sea interactions during a cold air outbreak over the Gulf Stream. Mon Weather Rev 128:973-996

Yu L, Weller RA (2007) Objectively analyzed air-sea heat fluxes for the global ice-free oceans (1991-2005). Bull Am Meteorol Soc $88: 527-539$

Yu L, Jin X, Weller RA (2008) Multidecade global flux datasets from the Objectively Analyzed Air-Sea fluxes (OAFlux) Project: latent and sensible heat fluxes, ocean evaporation, and related surface meteorological variables. OAFlux Project Technical Report. OA-2008-01, Woods Hole Oceanographic Institution, Woods Hole, MA, p 64 